\title{
Differential Effects of Dietary Lipids on Growth Performance, Digestibility, Fatty Acid Composition and Histology of African Catfish (Heterobranchus longifilis) Fingerlings
}

\author{
Theophilus Olayiwola Babalola, David Friday Apata ${ }^{2}$, James Sunday Omotosho ${ }^{3}$, Musibau Ayinde Adebayo ${ }^{4}$ \\ ${ }^{1}$ National Institute for Freshwater Fisheries Research, New-Bussa, Nigeria; ${ }^{2}$ Department of Animal Production, University of Ilorin, \\ Ilorin, Nigeria; ${ }^{3}$ Department of Zoology, University of Ilorin, Ilorin, Nigeria; ${ }^{4}$ Department of Chemistry, University of Ilorin, Ilorin, \\ Nigeria. \\ Email: tobabalola@yahoo.com
}

Received August 15 $5^{\text {th }}, 2010$; revised September $29^{\text {th }}, 2010$; accepted October $30^{\text {th }}, 2010$.

\begin{abstract}
The present study was performed to investigate the influence of fish oil (FO), two terrestrial animal fats (lard (PL) and poultry oil (CF)) and three vegetable oils (palm kernel (PKO), sheabutter (SBO) and sunflower (SFO)) as the dietary lipid sources on the growth performance, nutrient digestibility, fatty acid (FA) composition and histology of Heterobranchus longifilis. Six isonitrogenous and isoenergetic diets containing $6 \%$ of added fat from the lipid sources were formulated and used. Each diet was fed to triplicate groups of 20 fish. The lipid source influenced $(P<0.05)$ weight gain, specific growth rate, feed conversion ratio, hepatosomatic index and nutrient digestibility. Liver morphology of $H$. longifilis fed CF showed intense steatosis with hepatocytes containing numerous lipid vacuoles. However, fish fed PKO and SFO showed regular-shaped hepatocytes with few lipid vacuoles in the cytoplasm. Fillet FA profile of fish fed PKO, $S B O, P L$ and $C F$ diets had significantly higher $(P<0.05)$ concentrations of SFA and MUFA, but lower PUFA compared to fish fed FO and SFO diets. Fillet of fish fed the FO diet had higher $(P<0.05)$ concentrations of EPA and DHA compared with fish fed the other diets. The results of this study shows that alternative lipids sources could be used in $H$. longifilis diets however, inclusion of $\mathrm{PKO}$ or $\mathrm{SBO}$ in the diet of $\mathrm{H}$. longifilis produced fillets with low concentrations of long chain n-3 PUFA.
\end{abstract}

Keywords: Growth Performance, Polyunsaturated Fatty Acids, Heterobranchus longifilis, Histology

\section{Introduction}

One important ingredient of commercial aquaculture feeds is fish oil. It has been estimated that aquafeeds currently use about $60 \%$ of the global supply of fish oil, and that by the year 2010, it will be about $75 \%$ [1]. Fish oil is produced from small marine pelagic fish and represents a finite fishery resource. Over the past decade, global fish oil production has reached a plateau due to overexploitation of many capture fisheries. Therefore, in order to sustain the rapid growth of the global aquaculture industry; it is becoming increasingly crucial for the aquafeed industry to evaluate alternatives to fish oils.

Many authors have addressed the issue of fish oil replacement in aquafeeds [2,3], but to date, the works on $H$. longifilis are relatively limited. Fish oil replacement with alternative lipid sources seems to be possible if the essential fatty acid (EFA) requirements are satisfied [4]. Fatty acids (FA) are well known to have multifunctional effects on the metabolism of fish. Fatty acids supply energy and are components of membranes, pheromones and hormones [5].

Fish are unable to synthesize the EFA, such as linoleic (18:2 n-6) and linolenic acid (18:3n-3) de novo. Therefore, fish must obtain these substances via food [6]. The requirements of EFA for high growth rates of some cultured fish species are well investigated and most of them have a species-dependent demand for $n-3$ and $n-6$ FA. In general, it appears that cold water fish require PUFA of $n-3$ series, whereas warm water species need PUFA from either the $n-3$ and $n-6$ series. For example, salmonids fed with high amounts of linolenic acid (18:3n-3) obtain 
optimal growth rates [7]. Japanese eel (Anguilla japonica) and common carp require both $n-3$ and $n-6$ FA and tropical warm water species like Tilapia zilli have a higher need for $n-6$ than for $n-3$ [6]. Some freshwater fish can elongate and desaturate FAs with 18 carbons, specifically linolenic acid to PUFA with 20-22 carbons of the $n-3$ series. This ability to synthesize EPA and DHA from linolenic acid allows the formulation of diets containing less expensive plant oils/animal fats. The market value of cultured fish largely depends on their quality and feed composition is one of the factors that control quality $[8,9]$. It is currently well established that increased fish consumption in human is associated with decreased mortality, as well as morbidity from cardiovascular disease (CVD) and coronary heart disease (CHD) $[10,11]$. Consequently, the links between fish as food and human health are strongly related to the fatty acid composition of the food [12-14]. The fatty acid profile of fish can be modified with diets containing alternative lipid sources [13]. H. longifilis is an economical food fish cultured primarily in freshwater ponds in tropical countries. It is a candidate for commercial culture because of its special qualities which include hardiness, rapid growth, disease resistance, high yield potential, high fecundity, air breathing, and good market potential [15]. This study was undertaken to determine the effects of the alternative lipids on growth, histology, fillet and liver fatty acid composition of $\mathrm{H}$. longifilis, the subject of this study.

\section{Materials and Methods}

\subsection{Oil Sources and Experimental Diets}

Cod liver oil (FO) was purchased from a pharmaceutical shop, Palm kernel oil (PKO), sheabutter oil (SBO) and sunflower oil (SFO) were purchased from a local market in Ilorin, Nigeria. Lard (PL) and chicken fat (CF) were obtained from Nabest food company (Ogbomoso, Nigeria). The six experimental diets (Table 1) were formulated to contain either $6 \% \mathrm{FO}, \mathrm{PKO}, \mathrm{SBO}, \mathrm{PL}, \mathrm{SFO}$ or CF. Fish oil was used in the control diet and was completely replaced with the alternative lipid sources in the other five diets. The diets were formulated to contain similar content of total fat, protein and energy. This was confirmed by chemical analysis (Table 1). The difference in the diets was the lipid source, leading to variations in the fatty acid concentration of the diets (Table 2). The diets were made into pellet with meat mincer through $2 \mathrm{~mm}$ die, sundried, packed in polythene bags, sealed and stored at $-10^{\circ} \mathrm{C}$ until used.

Table 1. Composition of the experimental diets. $(\mathrm{g} / \mathrm{kg})$

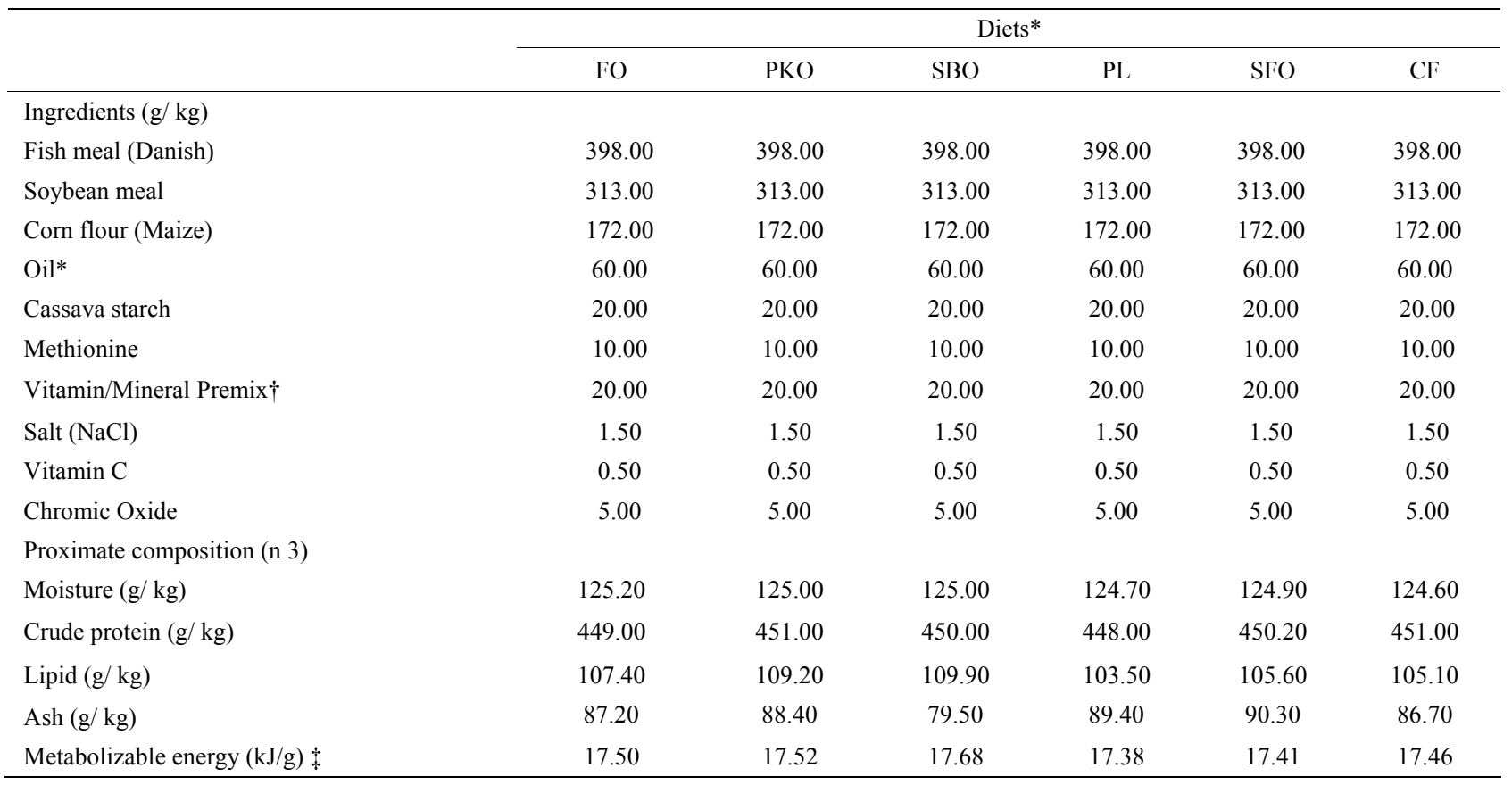

$* \mathrm{FO}=$ fish oil, $\mathrm{PKO}=$ palm kernel oil, $\mathrm{SBO}=$ sheabutter oil, $\mathrm{PL}=$ lard, $\mathrm{SFO}=$ sunflower oil, $\mathrm{CF}=$ chicken fat $\uparrow$ Vitamin/mineral premix supplied the following (per kg of diet): calcium, $4500 \mathrm{mg}$; phosphorus, $4200 \mathrm{mg}$; potassium, $1700 \mathrm{mg}$; magnesium, $400 \mathrm{mg}$; iron, $30 \mathrm{mg}$; zinc, $30 \mathrm{mg}$; manganese, $20 \mathrm{mg}$; copper, 5 mg; iodine, 1mg; selenium, $0.25 \mathrm{mg}$; vitamin A, $5000 \mathrm{IU}$; vitamin D, $2000 \mathrm{IU}$; DL- $\alpha$-tocopherol acetate, $100 \mathrm{mg}$; menadione, $15 \mathrm{mg}$; thiamine hydrochloride, 5 $\mathrm{mg}$; riboflavin, $10 \mathrm{mg}$; pyridoxine hydrochloride, $10 \mathrm{mg}$. Panthothenic acid, $35 \mathrm{mg}$; nicotinic acid, $50 \mathrm{mg}$; biotin, $0.5 \mathrm{mg}$; folic acid, $2 \mathrm{mg}$; ascorbic acid, $200 \mathrm{mg}$; inositol, $250 \mathrm{mg}$; choline, $400 \mathrm{mg}$; vitamin $\mathrm{B}_{12}, 0.1 \mathrm{mg}$ and ethoxyquin, $60 \mathrm{mg}$. $\$$ Calculated based on $16.70,16.70,37.70 \mathrm{~kJ} / \mathrm{g}$ for carbohydrate, protein and lipid, respectively. 
Table 2. Fatty acid composition of the experimental diets. (g/100g of total FA)

\begin{tabular}{|c|c|c|c|c|c|c|}
\hline & \multicolumn{6}{|l|}{ Diets * } \\
\hline & $\begin{array}{l}\mathrm{FO} \\
(\mathrm{n} 3)\end{array}$ & $\begin{array}{l}\text { PKO } \\
(n 3)\end{array}$ & $\begin{array}{l}\text { SBO } \\
(n 3)\end{array}$ & $\begin{array}{c}\text { PL } \\
(\text { n 3) }\end{array}$ & $\begin{array}{l}\text { SFO } \\
(n 3)\end{array}$ & $\begin{array}{c}\mathrm{CF} \\
(n 3)\end{array}$ \\
\hline \multicolumn{7}{|l|}{ Fatty acids } \\
\hline$\sum$ Saturates $\dagger$ & 30.12 & 80.74 & 50.30 & 30.02 & 18.85 & 36.83 \\
\hline$\sum$ monoenes: & 29.61 & 15.07 & 44.15 & 49.98 & 25.11 & 43.17 \\
\hline$\sum n-9 \S$ & 21.01 & 12.31 & 38.92 & 22.75 & 19.27 & 23.20 \\
\hline $18: 1 n-9$ & 9.72 & 11.79 & 38.76 & 21.01 & 18.87 & 21.56 \\
\hline$\sum n-6 \|$ & 13.57 & 2.41 & 4.3 & 14.59 & 46.13 & 14.45 \\
\hline $18: 2 n-6$ & 7.63 & 1.93 & 3.90 & 13.56 & 44.91 & 14.61 \\
\hline $20: 4 n-6$ & 0.92 & 0.25 & 0.09 & 5.15 & 0.51 & 0.27 \\
\hline$\sum n-39$ & 26.69 & 1.68 & 1.24 & 5.35 & 9.9 & 5.39 \\
\hline $18: 3 n-3$ & 1.49 & 0.22 & 0.01 & 1.60 & 0.28 & 1.59 \\
\hline $20: 5 n-3$ & 11.08 & 0.51 & 0.09 & 5.15 & 4.32 & 5.12 \\
\hline $22: 6 n-3$ & 12.75 & 0.52 & 0.08 & 8.02 & 3.74 & 8.09 \\
\hline$n-3 / n-6$ & 1.97 & 0.97 & 0.29 & 0.97 & 0.21 & 0.94 \\
\hline
\end{tabular}

$* \mathrm{FO}=$ fish oil, $\mathrm{PKO}=$ palm kernel oil, $\mathrm{SBO}=$ sheabutter oil, $\mathrm{PL}=$ lard, $\mathrm{SFO}=$ sunflower oil, $\mathrm{CF}=$ chicken fat. $\dagger$ Contains 12:0, 14:0, 16:0, 18:0, 20:0, 22:0, and 24:0. +Contains 16:1 n-9, 16:1 n-7, 18:1 n-9, 18:1 n-7, 20:1 n-11, 22:1 n-11 and 24:1 n-9. §Contains 16:1 n-9, 18:1 n-9, and 24:1 n-9. $\|$ Contains 18:2 n-6, 18:3 n-6, 18:4 n-6, 20:2 n-6, 20:3 n-6, 20:4 n-6, 22:2 n-6, 22:3 n-6, 22:4 n-6 and 22:5 n-6. ๆContains 18:3 n-3, 18:4 n-3, 20:4 n-3, 20:5 n-3, 22:5 n-3 and 22:6 $n-3$.

The $H$. longifilis fingerlings were obtained from the National Institute for Freshwater Fisheries Research (New-Bussa, Nigeria). Upon arrival fish were stocked in 60-litre plastic tanks in a flow-through system and acclimated to laboratory conditions for two weeks. During acclimation, fish were fed to apparent satiation twice a day using a commercial feed. Group of 20 fish were batch weighed and stocked into each tank. Three tanks were randomly assigned to each diet group. Water quality was maintained by continuous aeration and a flow rate of 1 litre per minute per tank. Dissolved oxygen and ammonia levels were within the normal range recommended for catfish [16]. A diurnal light/dark cycle of $12: 12 \mathrm{~h}$, water temperature of $26 \pm 1{ }^{\circ} \mathrm{C}$ and $\mathrm{pH}$ of $6.9 \pm$ 0.2 were maintained during the feeding trial. Fish were fed to apparent satiation twice daily (09:00 and 16:00) for twelve weeks. Fish in each tank were counted and weighed every two weeks.

\subsection{Sample Collection and Analysis}

The faecal material egested between the two feeds (day-time collection) was negligible and irregular. As such, only the faecal material collected overnight was used for the study. Admittedly, there would have been a certain degree of leaching of nutrient material from the faeces, and as such would affect the digestibility estimations, but such effects are believed to be minimal [17]. Furthermore, as the same procedure was adopted for all the diets this should not influence the results on the comparison of the different oil types. Pellets of faecal matter were siphoned out, taking care not to break, and sundried. As the amount of material collected each day was insufficient to perform all the chemical analyses, faecal matter collected over ten consecutive days was pooled, for each of the three replicates of each diet.

Apparent percent digestibility estimations were based on pooled faecal samples, from each replicate, for each of the diets. Faecal samples for each of the diets was analysed for dry matter, protein and total lipid in triplicate. The percent apparent dry matter (\%ADM), protein (\%PD) and lipid (\%LD) digestibility of the diets were determined using standard formulae [18]. The formulae used were:

$\% \mathrm{ADM}=100-\left[100\left(\mathrm{Cr}_{2} \mathrm{O}_{3}\right.\right.$ in diet $) \div\left(\mathrm{Cr}_{2} \mathrm{O}_{3}\right.$ in faeces)]

$\%$ Nutrient $=100-100\left[\left(\% \mathrm{Cr}_{2} \mathrm{O}_{3}\right.\right.$ in diet $) \div\left(\% \mathrm{Cr}_{2} \mathrm{O}_{3}\right.$ in faeces $)] \times[(\%$ nutrient in faeces $) \div(\%$ nutrient in feed)]

Diets were analysed for proximate composition using standard methods [19]. Moisture was determined gra- 
vimetrically after drying in oven at $105^{\circ} \mathrm{C}$ for $24 \mathrm{~h}$; ash by incineration in a muffle furnace at $450^{\circ} \mathrm{C}$ for $16 \mathrm{~h}$; protein $(\mathrm{N} \times 6.25)$ by the Kjeldahl method after acid digestion; lipids by petroleum ether extraction and chromic oxide of diet and faeces by acid digestion according to Furakawa and Tsukahara [20]. At the end of the trial, $H$. longifilis was fasted for $24 \mathrm{~h}$ and anesthetized with solution of methane sulphonate (MS222) [21]. The fish were then dissected and their liver removed and weighed for the determination of hepatosomatic index (HSI).

Liver samples were collected for histology from three fish per treatment. Samples were fixed in $10 \%$ buffered formalin, dehydrated in graded ethanol series and embedded in paraffin. Serial $4 \mu \mathrm{m}$ sections were stained with haematoxylin and eosin [22]. Stained sections were examined on a Carl Zeiss Axiophot microscope (Carl Zeiss Garden City, UK) for nuclear displacement and cytoplasm vacuolization.

Fatty acid analysis was performed on three samples of each experimental diet and pooled fillet and liver samples for the three replicates of each experimental treatment. The extraction of total lipids and preparation of fatty acid methyl esters was performed according to Sukhija and Palmquist [23]. Fatty acids methyl esters were separated by gas chromatography (GC) on a Varian Model 3300 gas chromatograph equipped with flame ionisation detector. A flexible fused silica Megabore column $(30 \mathrm{~m} \times 0.32 \mathrm{~mm}, 1 \mu \mathrm{m}$ film thickness $)$ with bonded stationary phase of CP-WAX was employed. Helium was used as the carrier gas at $1.0 \mathrm{ml} / \mathrm{min}$, inlet pressure $12 \mathrm{psi}$. Injector and the detector temperatures were 250 and $300^{\circ} \mathrm{C}$, respectively. The column temperature was programmed to be initially $140^{\circ} \mathrm{C}$ for $5 \mathrm{~min}$ and then to increase at a rate of $3{ }^{\circ} \mathrm{C}$ to a final temperature of $240^{\circ} \mathrm{C}$. Fatty acids methyl esters were identified in comparison to an external standard (Supelco ${ }^{\mathrm{TM}} 37$ component FAME Mix).

The data were subjected to analysis of variance (ANOVA) and if significant $(\mathrm{P}<0.05)$ differences were found, Duncan's multiple range test [24] was used to rank the group using SPSS version 13.0.

\section{Results}

\subsection{Growth Performance}

For the entire experimental period live weight of $H$. longifilis for the PL and PKO diets were higher $(P=$ 0.0001) than for the other diets (Table 3). Similar trends were evident for \%gain and specific growth rate (SGR). The SGR was highest in fish fed the PL and lowest $(P=$ $0.0001)$ for fish fed the SFO diet treatment.

The lowest $(P=0.001)$ FCR was observed for the FO treatment but it was not different from that of fish fed PKO, PL and MSO. Feed intake of fish was similar $(P=$ $0.44)$ for all the dietary groups. Significant differences $(P=0.0001)$ were observed among dietary treatments for HSI. Fish fed diet containing CF had the lowest liver weight; the highest value was obtained in fish fed SBO diet.

The apparent digestibility (AD) of dry matter (DM), protein $(\mathrm{P})$, and lipid $(\mathrm{L})$ of the experimental diets in $H$. longifilis is given in Table 3. The AD of DM (0.73-0.79) and nutrients of the diets were rather high $(\mathrm{P}$ and $\mathrm{L}$ ranged from 0.84 to 0.87 and 0.78 to 0.89 , respectively), and significant $(P=0.0001)$ differences among diets were observed for $\mathrm{AD}$ of $\mathrm{DM}, \mathrm{P}$ and $\mathrm{L}$. The $\mathrm{AD}$ of $\mathrm{DM}$, $\mathrm{P}$ and $\mathrm{L}$ were lowest for the SFO diet, and differed $(P=$ 0.0001) from those from the other diets.

Table 3. Growth performance and apparent nutrient digestibility of $\boldsymbol{H}$. longifilis fingerlings fed diets containing fish oil and alternative lipid sources for 10 weeks.

\begin{tabular}{|c|c|c|c|c|c|c|c|}
\hline & \multicolumn{6}{|l|}{ Diets* } & \multirow[b]{2}{*}{ SEM } \\
\hline & $\begin{array}{l}\mathrm{FO} \\
(n) 3)\end{array}$ & $\begin{array}{l}\text { PKO } \\
(n) 3)\end{array}$ & $\begin{array}{l}\text { SBO } \\
(n \text { 3) }\end{array}$ & $\begin{array}{l}\text { PL } \\
\text { (n 3) }\end{array}$ & $\begin{array}{l}\text { SFO } \\
\left(\begin{array}{ll}n & 3\end{array}\right)\end{array}$ & $\begin{array}{l}\text { CF } \\
(n 3)\end{array}$ & \\
\hline Initial weight (g) & 2.22 & 2.50 & 2.50 & 2.29 & 2.43 & 2.36 & 0.12 \\
\hline Weight gain (g) & $18.04^{\mathrm{c}}$ & $22.32^{\mathrm{d}}$ & $14.31^{\mathrm{b}}$ & $28.00^{\mathrm{e}}$ & $8.03^{\mathrm{a}}$ & $18.58^{\mathrm{c}}$ & 0.62 \\
\hline Feed intake (g) & $2.31^{\mathrm{ab}}$ & $2.43^{\mathrm{ab}}$ & $2.61^{\mathrm{bc}}$ & $2.62^{\mathrm{bc}}$ & $2.98^{\mathrm{c}}$ & $2.53^{\mathrm{abc}}$ & 0.11 \\
\hline FCR & $1.04^{\mathrm{ab}}$ & $1.06^{\mathrm{ab}}$ & $1.30^{\mathrm{b}}$ & $1.08^{\mathrm{ab}}$ & $1.94^{\mathrm{c}}$ & $1.13^{\mathrm{ab}}$ & 0.06 \\
\hline SGR & $2.99^{\text {cd }}$ & $3.13^{\mathrm{d}}$ & $2.51^{\mathrm{b}}$ & $3.57^{\mathrm{e}}$ & $1.71^{\mathrm{a}}$ & $2.88^{\mathrm{c}}$ & 0.04 \\
\hline HSI & $1.12^{\mathrm{b}}$ & $1.27^{\mathrm{c}}$ & $1.40^{\mathrm{d}}$ & $1.10^{\mathrm{b}}$ & $1.00^{\mathrm{ab}}$ & $0.53^{\mathrm{a}}$ & 0.04 \\
\hline Dry matter digestibility & $0.77^{\mathrm{c}}$ & $0.79^{\mathrm{e}}$ & $0.77^{\mathrm{c}}$ & $0.78^{\mathrm{d}}$ & $0.73^{\mathrm{a}}$ & $0.76^{\mathrm{b}}$ & 0.002 \\
\hline Protein digestibility & $0.76^{\mathrm{ab}}$ & $0.77^{\mathrm{bc}}$ & $0.76^{\mathrm{ab}}$ & $0.78^{\mathrm{c}}$ & $0.74^{\mathrm{a}}$ & $0.76^{\mathrm{ab}}$ & 0.003 \\
\hline Fat digestibility & $0.83^{\mathrm{c}}$ & $0.86^{\mathrm{d}}$ & $0.79^{\mathrm{ab}}$ & $0.89^{\mathrm{e}}$ & $0.78^{\mathrm{a}}$ & $0.80^{\mathrm{b}}$ & 0.005 \\
\hline
\end{tabular}

$\overline{\mathrm{FCR}}=$ feed conversion ratio (feed intake $/$ weight gain, $\mathrm{SGR}=$ specific growth rate $(100 \times(\ln [$ final body weight] - [initial body weight]/No. days), HSI $=$ hepatosomatic index $(100 \times($ liver weight $/$ body weight $) . * \mathrm{FO}=$ fish oil, $\mathrm{PKO}=$ palm kernel oil, $\mathrm{SBO}=$ sheabutter oil, $\mathrm{PL}=$ lard, $\mathrm{SFO}=$ sunflower oil, $\mathrm{CF}=$ chicken fat. ${ }^{\mathrm{a}, \mathrm{b}, \mathrm{c}}$ Means values in the same row followed by the same letters are not significantly different at $P>0.05$. 


\subsection{Histological Observations}

The clinical picture of the fish liver sections from the different groups is shown in Figures 1-3. Dietary lipid seams to induce lipid accumulation in the liver. Livers from fish fed CF diets showed apparent steatosis with intense lipid accumulation (Figure 1). The integrity of the hepatocytes was also affected; swelling and nuclei displacement were evident in the examined liver. The hepatocyte in livers from the FO, SBO, and PL (Figure 2) diet fed fish was associated with mild lipid accumulation with scattered irregularity in shape. Livers of fish fed the PKO and SFO (Figure 3) diets showed the best picture with regular-shaped hepatocytes having centrally located nuclei with no noticeable lipid accumulation in their cytoplasm.

\subsection{Fatty Acid Composition of the Diet and Fish Fillet}

The fatty acid analysis of dietary lipids reflected the ad-

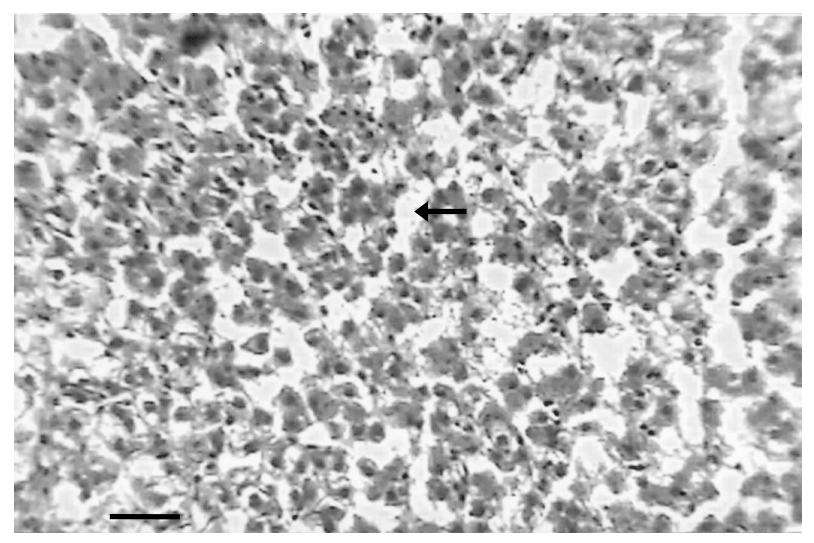

Figure 1. Liver of $\boldsymbol{H}$. longifilis fed CF. Hepatocytes with nuclei located at the peripheral of the cell wall and severe lipid infiltration (arrow) of the cytoplasm (H\&E, bar $=50$ $\mu \mathrm{m})$.

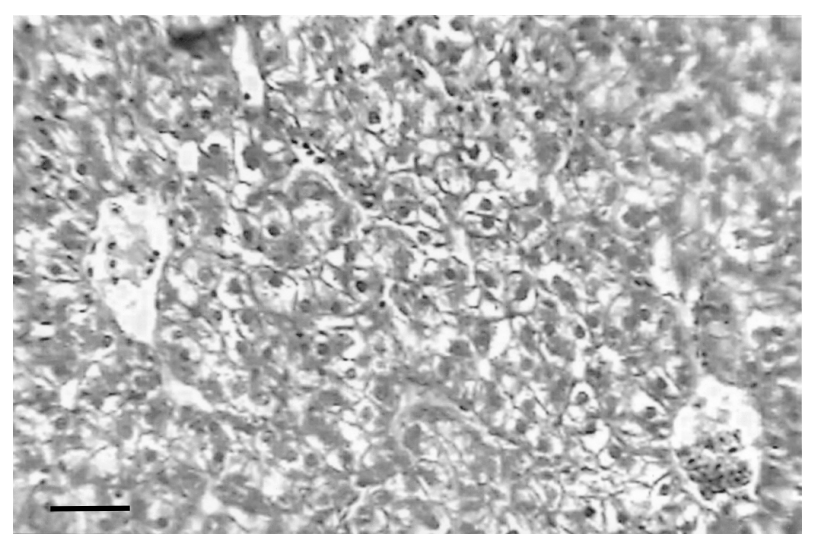

(a)

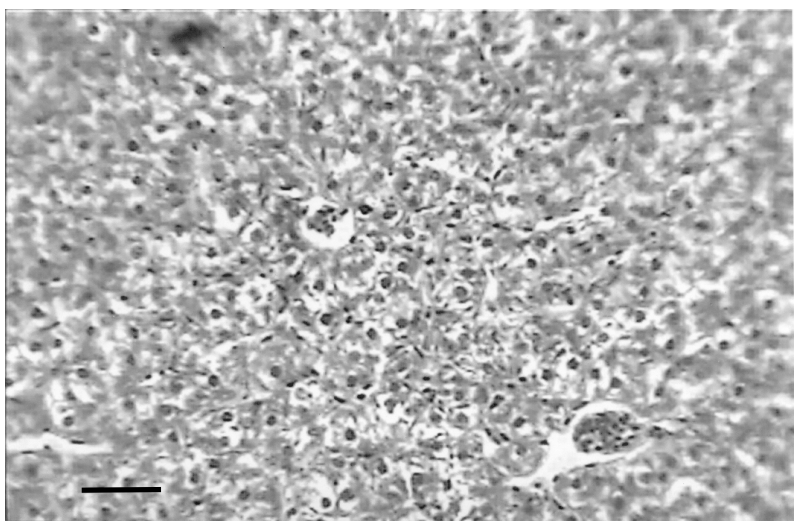

(b)

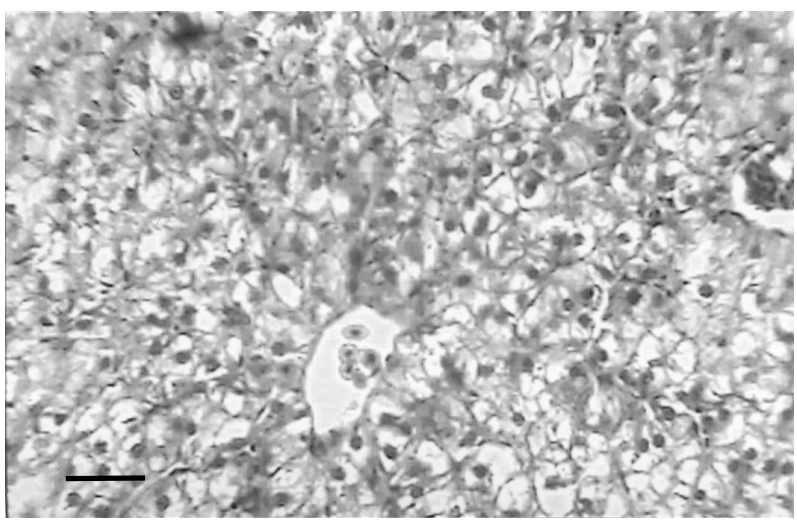

(c)

Figure 2. Liver of $\boldsymbol{H}$. longifilis fed FO (a), SBO (b) and PL (c) showing hepatocytes with nuclei located at the peripheral of the cell wall and lipid vacuoles in the cytoplasm $(\mathrm{H} \& \mathrm{E}$, bar $=\mathbf{5 0} \mu \mathrm{m})$.

dition of plant oils and animal fats and their main composition is given in Table 2. Total saturated fatty acidsranged from $18.85 \%$ in diet SFO to $80.84 \%$ in diet PKO. Oleic acid ranged from $9.72 \%$ in diet FO to $38.76 \%$ in diet SBO. Linoleic acid was highest in SFO diet $44.91 \%$, while the PKO diet contained the lowest percentage (1.93\%). Percentages of EPA ranged from 0.09 in SBO diet to $11.08 \%$ in FO diet (a $99 \%$ reduction compared to the FO diet), while DHA ranged from $0.08 \%$ in SBO diet to $12.75 \%$ in $\mathrm{FO}$ diet (a $99.40 \%$ reduction compared to FO diet). The $n-3 / n-6$ fatty acids ratio ranged from 0.21 in SFO to 1.97 in fish oil (a 95\% reduction compared to FO diet).

Fillet FA composition of total lipids varied with the lipid source used and reflected the FA profile of the diets (Table 4). Saturated FA proportion was reduced $(P=$ $0.0001)$ in the fillet of fish fed SFO diet whereas they were significantly increased $(P=0.0001)$ in the muscle of fish fed SBO diet. Oleic acid increased significantly in 


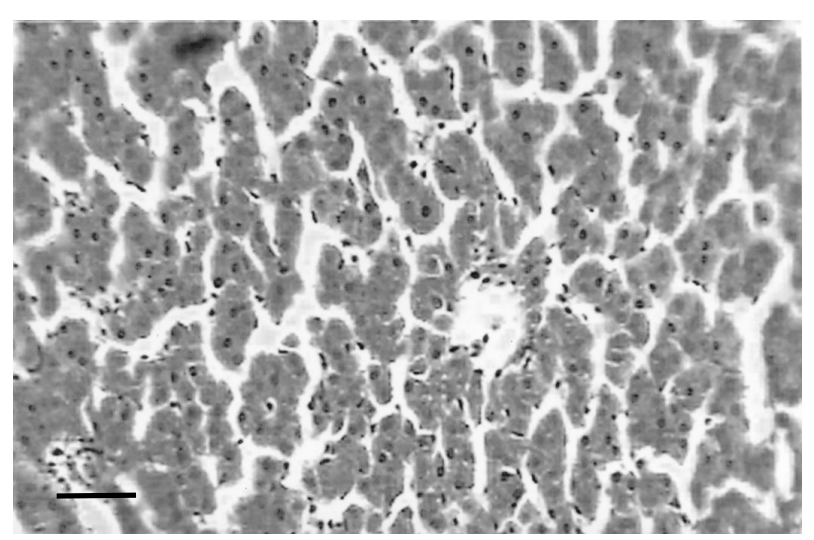

(a)

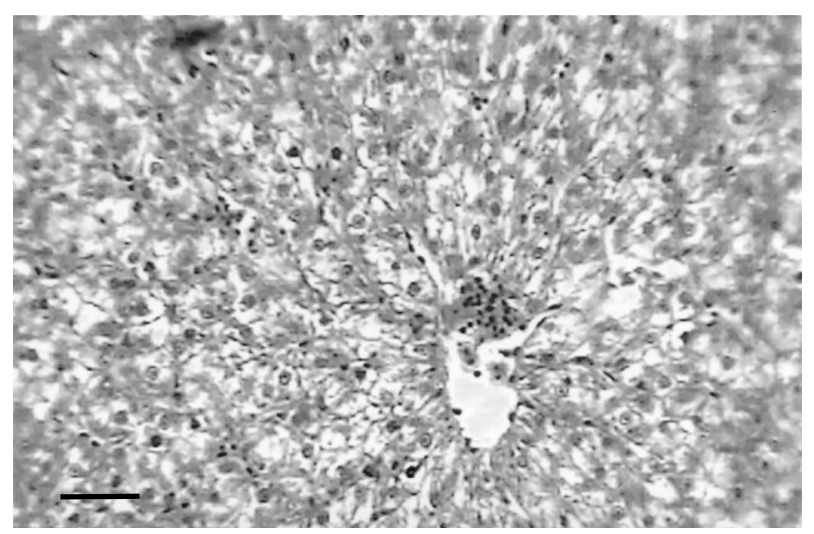

(b)

Figure 3. Liver of $\boldsymbol{H}$. longifilis fed PKO (a), SFO (b) showing hepatocytes with centrally located nuclei and some lipid vacuoles in the cytoplasm (H\&E, bar $=50$ $\mu \mathrm{m})$.

the fillet of fish fed alternative lipids. The highest increase was observed in fish fed PKO diet $(P=0.0001)$. Linoleic acid increased in the fillet of SFO fed fish, being 3.6 times higher than the FO dietary group. Total $n-6$ fatty acid (FA) were significantly reduced in fillet of fish fed SBO diet, largely due to significant lower 18:2n-6 and 20:4n-6 concentrations in the fillet. Total $n-3$ FA was significantly reduced in the fillet of fish fed the alternative lipid sources diets. The reduction was more pronounced for EPA than for DHA. These differences in individual fatty acid concentrations resulted in respective significant $n-3 / n-6$ reduction.

\subsection{Fatty Acid Profile of the Liver Fat}

Liver of fish fed SBO had higher $(P=0.001)$ concentration of total saturated FA (62.51\%) than for fish fed other lipid sources (Table 5). The SFO had the lowest concentration of saturated, total monoenes, total $n-9 \mathrm{FA}$ and 18:1n-9. Total saturated FA ranged from $20.74 \%$ in SFO fed fish to $62.51 \%$ in the SBO fed fish. The total monoenes FA concentrations were higher in PKO fed fish. Liver tissue of fish fed SFO diet was highest in $18: 2 n-6$, total $n-3,20: 5 n-3$ and $22: 6 n-3$ and those fish fed FO diet were higher in 18:3n-3.

Total $n$-6 FA in liver was similar in fish fed diets containing PKO and SBO and lower than in fish fed the other diets. Total n-3 FA in liver was highest in fish fed diets containing SFO and lowest in MSO fed fish. The ratio of $n-3$ to $n-6$ FA in liver was highest in fish fed FO diet, lowest in fish fed PKO and intermediate in fish fed the other diets.

\section{Discussions}

The results of this trial, where FO was substituted with alternative lipid sources, hold promise that complete replacement of marine FO with vegetable oil and animal fats alternatives is a possibility in $\mathrm{H}$. longifilis diet. Both vegetable and animal fats can meet the energy requirements of the fish by providing easily oxidized FA and, generate fillet fatty acid composition that are beneficial to the consumer by maximising retention of desirable FA such as DHA (22:6n-3) and EPA (20:4n-3).

This study demonstrated that feeding diets containing PL and PKO had significant effects on growth rate or feed conversion ratio above fish fed FO and other diets. This finding is consistent with previous studies showing successful partial or total replacement of dietary fish oil with vegetable oil in African catfish [25-27], rainbow trout [28], sharpsnout sea bream [29] and Atlantic salmon [30,31] without showing any negative impact on growth.

Fish eating diet containing SBO displayed a significant higher hepatosomatic index than those fed FO or other alternative lipid sources. This could be attributed to the digestibility of fish fed this diet, leading to lipid deposition in the liver enterocytes.

The apparent digestibility coefficients are high in all the experimental diets, with a lower value in the case of SFO. This may be due to a higher affinity of digestive lipases for some FA and/or to absorption rate and efficiency differences between FA leading to a different utilization of individual fatty acids [3].

The high apparent lipid digestibility values fell within the range of other studies in which practical diets were used [32-34], supporting the statement by Olsen and Ringe [35], that lipids are generally well digested by fish. The significant differences between the dietary treatments with regards to apparent lipid digestibility were similar to those reported for muray cod [36] when fish oil was substituted incrementally by a vegetable oil. In consideration that the experimental diets were isonitrogenous 
Table 4. Fatty acid composition (g/100g of total FA) and indexes related to human health in the fillet of $H$. longifilis fingerlings fed alternative lipid sources for 12 weeks.

\begin{tabular}{|c|c|c|c|c|c|c|c|}
\hline & \multicolumn{7}{|l|}{ Diets * } \\
\hline & $\begin{array}{c}\text { FO } \\
(n 3)\end{array}$ & $\begin{array}{l}\text { PKO } \\
(n 3)\end{array}$ & $\begin{array}{l}\text { SBO } \\
(n 3)\end{array}$ & $\begin{array}{c}\mathrm{PL} \\
(n 3)\end{array}$ & $\begin{array}{l}\text { SFO } \\
(n 3)\end{array}$ & $\begin{array}{c}\mathrm{CF} \\
(n 3)\end{array}$ & SEM \\
\hline \multicolumn{8}{|l|}{ Fatty acids } \\
\hline$\sum$ Saturates $\dagger$ & $31.96^{\mathrm{b}}$ & $45.44^{\mathrm{e}}$ & $62.04^{\mathrm{f}}$ & $34.08^{\mathrm{d}}$ & $23.65^{\mathrm{a}}$ & $32.90^{\mathrm{c}}$ & 0.01 \\
\hline$\sum$ monoenes & $27.45^{\mathrm{b}}$ & $47.58^{\mathrm{f}}$ & $28.39^{\mathrm{d}}$ & $28.17^{\mathrm{c}}$ & $22.03^{\mathrm{a}}$ & $30.58^{\mathrm{e}}$ & 0.02 \\
\hline$\sum n-9 \S$ & $20.75^{b}$ & $47.51^{\mathrm{f}}$ & $22.21^{\mathrm{c}}$ & $23.60^{\mathrm{e}}$ & $15.55^{\mathrm{a}}$ & $23.48^{\mathrm{d}}$ & 0.02 \\
\hline $18: 1 n-9$ & $13.75^{\mathrm{a}}$ & $47.30^{\mathrm{f}}$ & $20.93^{c}$ & $22.21^{\mathrm{e}}$ & $14.82^{\mathrm{b}}$ & $22.08^{\mathrm{d}}$ & 0.01 \\
\hline$\sum n-6 \|$ & $10.56^{\mathrm{c}}$ & $5.74^{\mathrm{b}}$ & $5.17^{\mathrm{a}}$ & $14.65^{\mathrm{d}}$ & $32.29^{\mathrm{f}}$ & $14.95^{\mathrm{e}}$ & 0.01 \\
\hline $18: 2 n-6$ & $8.03^{\mathrm{c}}$ & $4.78^{\mathrm{b}}$ & $3.43^{\mathrm{a}}$ & $12.91^{\mathrm{e}}$ & $28.99^{\mathrm{f}}$ & $12.94^{\mathrm{d}}$ & 0.01 \\
\hline $20: 4 n-6$ & $1.46^{\mathrm{f}}$ & $0.29^{\mathrm{a}}$ & $1.23^{\mathrm{c}}$ & $1.27^{\mathrm{e}}$ & $1.24^{\mathrm{d}}$ & $1.10^{\mathrm{b}}$ & 0.01 \\
\hline$\sum n-39$ & $30.03^{\mathrm{e}}$ & $1.15^{\mathrm{a}}$ & $3.41^{\mathrm{b}}$ & $23.10^{\mathrm{d}}$ & $22.02^{\mathrm{c}}$ & $21.57^{\mathrm{c}}$ & 0.17 \\
\hline $18: 3 n-3$ & $1.14^{\mathrm{d}}$ & $0.93^{\mathrm{c}}$ & $0.02^{\mathrm{a}}$ & $1.39^{\mathrm{f}}$ & $0.29^{\mathrm{b}}$ & $1.29^{\mathrm{e}}$ & 0.01 \\
\hline $20: 5 n-3$ & $8.78^{\mathrm{f}}$ & $0.08^{\mathrm{a}}$ & $0.70^{\mathrm{b}}$ & $5.77^{\mathrm{d}}$ & $4.02^{\mathrm{c}}$ & $5.84^{\mathrm{e}}$ & 0.01 \\
\hline $22: 6 n-3$ & $18.30^{\mathrm{f}}$ & $0.27^{\mathrm{a}}$ & $2.43^{\mathrm{b}}$ & $14.76^{\mathrm{d}}$ & $15.87^{\mathrm{e}}$ & $13.35^{\mathrm{c}}$ & 0.02 \\
\hline$n-3 / n-6$ & $2.84^{\mathrm{f}}$ & $0.20^{\mathrm{a}}$ & $0.85^{\mathrm{c}}$ & $1.58^{\mathrm{e}}$ & $0.68^{\mathrm{b}}$ & $1.44^{\mathrm{d}}$ & 0.01 \\
\hline
\end{tabular}

*FO $=$ fish oil, $\mathrm{PKO}=$ palm kernel oil, $\mathrm{SBO}=$ sheabutter oil, $\mathrm{PL}=$ lard, $\mathrm{SFO}=$ sunflower oil, $\mathrm{CF}=$ chicken fat; ${ }^{\text {a,b,c }}$ Means values in the same row followed by the same letters are not significantly different at $P>0.05$; $†$ Contains 12:0, 14:0, 16:0, 18:0, 20:0, 22:0, and 24:0; $\$$ Contains 16:1 $n-9,16: 1 n-7,18: 1 n-9,18: 1$ $n-7,20: 1 n-11,22: 1 n-11$ and 24:1 n-9. §Contains 16:1 n-9, 18:1 n-9, and 24:1 n-9. I| Contains18:2 n-6, 18:3 n-6, 18:4 n-6, 20:2 n-6, 20:3 n-6, 20:4 n-6, 22:2 $n-6,22: 3 n-6,22: 4 n-6$ and 22:5 n-6. ๆContains 18:3 n-3, 18:4 n-3, 20:4 n-3, 20:5 n-3, 22:5 n-3 and 22:6 n-3.

Table 5. Liver fatty acid composition (g/100 g of total FA)of $H$. longifilis fed alternative lipid sources for 12 weeks.

\begin{tabular}{|c|c|c|c|c|c|c|c|}
\hline & \multicolumn{7}{|l|}{ Diets * } \\
\hline & $\begin{array}{c}\mathrm{FO} \\
(n 3)\end{array}$ & $\begin{array}{l}\text { PKO } \\
(n 3)\end{array}$ & $\begin{array}{l}\text { SBO } \\
(n 3)\end{array}$ & $\begin{array}{l}\text { PL } \\
\text { (n 3) }\end{array}$ & $\begin{array}{l}\text { SFO } \\
(n 3)\end{array}$ & $\begin{array}{c}\mathrm{CF} \\
(\text { n 3) }\end{array}$ & SEM \\
\hline \multicolumn{8}{|l|}{ Fatty acids } \\
\hline$\sum$ Saturates $\dagger$ & $42.52^{\mathrm{d}}$ & $45.68^{\mathrm{e}}$ & $61.51^{\mathrm{f}}$ & $39.31^{\mathrm{c}}$ & $20.74^{\mathrm{a}}$ & $37.15^{\mathrm{b}}$ & 0.02 \\
\hline$\sum$ monoenes & $45.02^{\mathrm{c}}$ & $52.64^{d}$ & $35.87^{\mathrm{b}}$ & $45.89^{\mathrm{c}}$ & $25.65^{\mathrm{a}}$ & $46.20^{c}$ & 0.58 \\
\hline$\sum n-9 \S$ & $29.77^{b}$ & $52.79^{\mathrm{f}}$ & $30.74^{\mathrm{c}}$ & $35.41^{\mathrm{e}}$ & $21.86^{\mathrm{a}}$ & $34.51^{\mathrm{d}}$ & 0.02 \\
\hline $18: 1 n-9$ & $27.32^{\mathrm{b}}$ & $52.71^{\mathrm{f}}$ & $30.34^{\mathrm{c}}$ & $33.45^{\mathrm{e}}$ & $20.19^{\mathrm{a}}$ & $32.65^{d}$ & 0.01 \\
\hline$\sum n-6 \|$ & $4.92^{\mathrm{b}}$ & $1.20^{\mathrm{a}}$ & $1.13^{\mathrm{a}}$ & $7.00^{\mathrm{c}}$ & $36.29^{\mathrm{e}}$ & $7.18^{\mathrm{d}}$ & 0.02 \\
\hline $18: 2 n-6$ & $3.53^{\mathrm{b}}$ & $0.87^{\mathrm{a}}$ & $0.82^{\mathrm{a}}$ & $6.15^{\mathrm{c}}$ & $28.56^{\mathrm{d}}$ & $6.07^{\mathrm{c}}$ & 0.02 \\
\hline $20: 4 n-6$ & $0.99^{\mathrm{e}}$ & $0.05^{\mathrm{a}}$ & $0.25^{\mathrm{b}}$ & $0.63^{\mathrm{c}}$ & $3.84^{\mathrm{f}}$ & $0.81^{\mathrm{d}}$ & 0.01 \\
\hline$\sum n-39$ & $8.86^{\mathrm{d}}$ & $0.29^{\mathrm{a}}$ & $0.50^{\mathrm{b}}$ & $7.80^{\mathrm{c}}$ & $17.31^{\mathrm{f}}$ & $9.47^{\mathrm{e}}$ & 0.01 \\
\hline $18: 3 n-3$ & $0.54^{\mathrm{f}}$ & $0.17^{\mathrm{c}}$ & $0.01^{\mathrm{a}}$ & $0.46^{\mathrm{d}}$ & $0.10^{\mathrm{b}}$ & $0.51^{\mathrm{e}}$ & 0.01 \\
\hline $20: 5 n-3$ & $2.31^{\mathrm{e}}$ & $0.01^{\mathrm{a}}$ & $0.10^{\mathrm{b}}$ & $1.90^{\mathrm{c}}$ & $2.92^{\mathrm{f}}$ & $2.10^{\mathrm{d}}$ & 0.01 \\
\hline $22: 6 n-3$ & $5.33^{\mathrm{d}}$ & $0.02^{\mathrm{a}}$ & $0.19^{\mathrm{b}}$ & $5.05^{\mathrm{c}}$ & $13.28^{\mathrm{f}}$ & $6.37^{\mathrm{e}}$ & 0.01 \\
\hline$n-3 / n-6$ & $1.80^{\mathrm{f}}$ & $0.24^{\mathrm{a}}$ & $0.44^{\mathrm{b}}$ & $1.11^{\mathrm{d}}$ & $0.48^{\mathrm{c}}$ & $1.32^{\mathrm{e}}$ & 0.01 \\
\hline
\end{tabular}

$* \mathrm{FO}=$ fish oil, $\mathrm{PKO}=$ palm kernel oil, $\mathrm{SBO}=$ sheabutter oil, $\mathrm{PL}=$ lard,, $\mathrm{SFO}=$ sunflower oil, $\mathrm{CF}=$ chicken fat; ${ }^{\mathrm{a}, \mathrm{b}, \mathrm{c}}$ Means values in the same row followed by the same letters are not significantly different at $P>0.05$; $\dagger$ Contains $12: 0,14: 0,16: 0,18: 0,20: 0,22: 0$, and $24: 0 ;+C o n t a i n s ~ 16: 1 n-9,16: 1 n-7,18: 1 n-9,18: 1 n-7$, 20:1n-11, 22:1n-11 and 24:1n-9; §Contains 16:1n-9, 18:1n-9, and 24:1n-9; || Contains 18:2n-6, 18:3n-6, 18:4n-6, 20:2n-6, 20:3n-6, 20:4n-6, 22:2n-6, 22:3n-6, $22: 4 n-6$ and 22:5n-6; Contains 18:3n-3, 18:4n-3, 20:4n-3, 20:5n-3, 22:5n-3 and 22:6n-3. 
and isolipidic these differences were likely attributable to differences in the individual FA composition of each diet.

In fish it is well known that FA digestibility decreases with increasing chain length [37]. Thus the digestibility of saturated FA is 14:0 $>16: 0>18: 0$. This could be the reason for improved digestibility and growth performance recorded for PL and PKO fed fish.

Steatosis is classically described as a relatively mild liver alteration due to an excessive (or unbalanced) dietary intake of lipids which saturate the physiological capacity of the liver to handle, thus leading to lipid droplet (triglycerides) accumulation. The synthesis and degradation of FA occurred mainly in the liver, and several enzymes regulating these pathways show varying affinities for the different fatty acids available in the organ [38], thus imbalance in the dietary fatty acids could modify the functioning and morphology of this organ. In addition, liver function as a main energy reservoir, frequently in the form of triacylglycerols (TG), in certain species such as cod [39], sea bream or sea bass [40]. Thus, when dietary lipid or energy exceeds the capacity of the hepatic cells to oxidize fatty acids, or when protein synthesis is impaired, the result is the large synthesis and deposition of TG in vacuoles, leading to a morphological pattern known as steatosis. Liver steatosis has been frequently observed associated with nutritional imbalances in cultured fish [41]. In sea bream, steatosis has been observed as a result of an EFA deficiency [42], the use of artificial diets [43] and the inclusion of vegetable oils [44]. When Sparus auratus and D. labrax were fed diets differing in lipid composition, steatotic livers were observed in fish fed on diets characterized by low PUFA/MUFA ratio. Liver histological sections of fish in this study showed an extensive infiltration of lipid droplets in hepatocytes, especially in fish fed diets containing CF. These morphological changes could be associated with nutritional imbalance in terms of EFAs-18:2n-6 and 18:3n-3.

The essential fatty acid requirements for $H$. longifilis are not known, but the results of this study suggest that they may be low compared with channel catfish that require $0.5-0.75 \%$ EPA and DHA [45]. Since there was no observable symptoms of EFA deficiency such as fin erosion, a shock syndrome, myocarditis, reduced growth rate, reduced feed efficiency, and increased mortality $[45,46]$ in any of the dietary treatments. It appears that the percentage of fishmeal contained in all diets provides a sufficient amount of EFA. Also in fish species like $H$. longifilis that can desaturate and chain elongate 18:2n-6 or 18:3n-3, an absence of either of these fatty acids in the diet has been showed leads to the desaturation and chain elongation of oleic acid, $18: 1 n-9$, to $20: 3 n-9$, which is characteristic of an EFA deficiency in many terrestrial animals [45]. Thus when EFA are deficient, increased concentrations of 20:3n-9 are incorporated into tissue lipids in place of $20: 4 n-6,20: 5 n-3$, or $22: 6 n-3$. The lower concentration of 20:3n-9 and increased concentrations of 20:4n-6, 20:5n-3 and 22:6n-3 in the tissue of H. longifilis showed that the dietary EFA requirements are met.

This study, with total replacement of fish oil with alternative lipid sources shows that specific FA were selectively retained in the fillet of the fish; especially DHA and arachidonic acid (AA) concentrations were higher than the dietary concentrations. Similar results were also found for gilthead sea bream (Sparus aurata L.) [47], European sea bass [48,49], rainbow trout [32] and turbot [50]. The same effect was also observed in liver, where DHA and AA concentrations showed a preference in the retention which is in accordance with Menoyo et al. [51] in gilthead sea bream and Torstensen et al. [52] in Atlantic salmon. The selective retention of DHA could be related to the higher beta-oxidation of eicosapentaenoic acid (EPA) compared to DHA [53], due to the complex catabolism of this fatty acid [54]. This probably indicates a selective catabolism of EPA over DHA when dietary levels decrease, possibly to meet the requirement for tissue membrane composition and function. The reduction of EPA in both fillet and liver at a lesser extent than its respective dietary concentration suggest utilization of this fatty acid.

In fish fed SFO diet, palmitic acid (16:0) concentrations in the liver were low comparing to dietary concentrations. Suggesting that liver metabolism is predisposed to treat 16:0 differently than most other fatty acids and its level is more tightly controlled than for other tissues. This was also observed in rainbow trout [28] and gilthead sea bream [47]. Palmitic acid is an important component of phospholipids, especially at the sn-1 position of phosphatidylcholine and to a lesser extent, phosphatidylethanolamine. The presence of dietary phospholipids improves lipid digestibility, absorption and transport $[55,56]$. Olsen et al. [57,58] suggest that diet containing phospholipids have a higher apparent lipid digestibility than diets containing high amount of triacylglycerols. This supports the observation in this study that fish on PL and PKO had higher apparent lipid digestibility than those from the other group, because of their higher concentrations of palmitic acid which is a component of phospholipids.

In conclusion, this study showed that $H$. longifilis performed optimally on diets containing PKO, PL and CF with respect to weight gain, specific growth rate, feed intake and feed conversion ratio.

Therefore, it is recommended that PKO, PL and CF be 
added to the diet of $H$. longifilis for improved growth performance and better nutrient utilization. However, further study aimed at increasing the concentration of the long chain polyunsaturated fatty acid in the fillet is needed.

\section{REFERENCES}

[1] S. Barlow, "Fishmeal and Fish Oil: Sustainable Feed Ingredients for Aquafeeds," Global Aquacult. Advocate, Vol. 3, No. 2, 2000, pp. 85-88.

[2] G. M. Turchini, V. M. Moretti and F. Valfre, "A Brief Review on Alternative Lipid Sources for Aquafeeds," Rivista Italiana di Acquacoltura, Vol. 35, 2000, pp. 91-108.

[3] R. M. Gunasekera, K. Leelarasamee and S. S. De Silva, "Lipid and Fatty Acid Digestibility of Three Oil Types in the Australian Shortfin Eel," Anguilla australis. Aquaculture, Vol. 203, 2002, pp. 335-347.

[4] J. Sargent, G. Bell, L. Mc Evoy, D. Tocher and A. Estevez, "Recent Developments in the Essential Fatty Acid Nutrition in Fish," Aquaculture, Vol. 177, 1999, pp. 191199.

[5] J. R. Sargent, R. J. Henderson and D. R. Tocher, "The Lipids," In: J. E. Halver, Ed., Fish Nutrition, 2nd Edition, Academic Press, New York, 1989, pp. 154-218.

[6] T. Takeuchi, S. Arai, T. Watanabe and Y. Shimma, "Requirement of Eel Anguilla Japonica for Essential Fatty Acids," Bulletin of the Japanese Society of Scientific Fisheries, Vol. 46, No. 3, 1980, pp. 345-353.

[7] T. Watanabe, "Lipid Nutrition in Fish," Comparative Biochemistry and Physiology, Vol. 73B, 1982, pp. 3-15.

[8] P. C. Morris, "The Effect of Nutrition on the Composition of Farmed Fish," In: S. C. Kestin and P. D. Warriss, Eds., Farmed Fish Quality, Fishing News Books, Blackwell Science, London, 2001, pp. 161-179.

[9] K. D. Shearer, "The Effect of Diet Composition and Feeding Regime on the Proximate Composition of Farmed Fishes," In: S. C. Kestin and P. D. Warriss, Eds., Farmed Fish Quality, Fishing News Books, Blackwell Science, London, 2001, pp. 31-41.

[10] W. E. Connor, "Importance of N-3 Fatty Acids in Health and Disease," American Journal of Clinical Nutrition, Vol. 71, Suppl. 1, 2000, pp. 171S-175S.

[11] M. T. Arts, R. G. Ackman and B. J. Holub, “"Essential Fatty Acids' in Aquatic Ecosystems: A Crucial Link between Diet and Human Health and Evolution," Canadian Journal of Fisheries and Aquatic Sciences, Vol. 58, No. 1, 2001, pp. 122-137.

[12] M. A. Crawford, S. C. Cunnanes and L. S. Harbige, "A New Theory of Evolution: Quantum Theory," In: A. J. Sinclair and R. Gibson, Eds., Proceedings of the 3rd International Congress on Essential fatty acids and Eicosanoids, Association of Official Analytical Chemists Press, Adelaide, Australia, 1993, pp. 87-95.

[13] W. Steffens, "Effects of Variation in Essential Fatty Ac- ids in Fish Feeds on Nutritive Value of Freshwater Fish for Humans," Aquaculture, Vol. 151, 1997, pp. 97-119.

[14] G. Valdimarsson and D. James, "World Fisheries-Utilisation of Catches," Ocean \& Coastal Management, Vol. 44, No. 9-10, 2001, pp. 619-633.

[15] T. O. O. Babalola, and D. F. Apata, "Effects of Dietary Protein and Lipid Levels on Growth Performance and Body Composition of African catfish Heterobranchus longifilis (Valenciennes, 1840) Fingerlings," Journal of Animal and Veterinary Advances, Vol. 5, No. 12, 2006, pp. 1073-1079.

[16] W. J. Viveen, C. J. J. Richter, P. G. W. J. Van Oordt, J. A. L. Janseen and E. A. Huisman, "Practical Manual for the Culture of the African Catfish (Clarias gariepinus)," Purdoc, the Hague, the Netherlands, 1985, pp. 121.

[17] S. Satoh, C. Y. Cho and T. Watanabe, "Effect of Faecal Retrieval Timing on Digestibility of Nutrients in Rainbow Trout Diet with the Guelph and TUF Faeces Collection Systems," Bulletin of the Japanese Society of Scientific Fisheries, Vol. 58, 1992, pp. 1123-1127.

[18] L. A. Maynard, J. K. Loosli, H. F. Hintz and R. G. Warner, "Animal Nutrition," 7th Edition, McGraw-Hill, New York, 1979.

[19] AOAC, "Official Methods of Analysis of AOAC," 14th Edition, Association of Official Analytical Chemists, Washington, DC, 1984.

[20] A. Furukawa and H. Tsukahara, "On the Acid Digestion Method for the Determination of Chromic Oxide as an Indicator Substance in the Study of Digestibility in Fish," Bulletin of the Japanese Society of Scientific Fisheries, Vol. 32, 1966, pp. 502-506.

[21] E. J. Wagner, T. Jeppsen, R. Arndt, M. D. Routledge and Q. Bradwisch, "Effects of Rearing Density Upon Cutthroat Trout Hematology, Hatchery Performance, Fin Erosion and General Health and Condition," The Progressive Fish-Culturist, Vol. 59, No. 3, 1997, pp. 173-187.

[22] R. Martoja and M. Martoja-Pierson, "Te'cnicas de Histologi'a Animal,” S. A. Toray-Masson, Ed., Barcelona, 1970.

[23] P. S. Sukhija and D. L. Palmquist, "Rapid Method for Determination of Total Fatty Acid Content and Composition of Feedstuffs and Feces," Journal of Agricultural Food Chemistry, Vol. 36, No. 3, 1988, 1202-1206.

[24] D. B. Duncan, "Multiple Range and Multiple (F) Test," Biometrics, Vol. 11, No. 1, 1955, pp. 1-42.

[25] P. K. Lim, P. L. Boey and W. K. Ng, "Dietary Palm Oil Level Affects Growth Performance, Protein Retention and Tissue Vitamin E Concentration of African Catfish, Clarias gariepinus," Aquaculture, Vol. 202, No. 1-2, 2001, pp. 101-112.

[26] W. K. Ng, P. K. Lim, and P. L. Boey, "Dietary Lipid and Palm Oil Source Affects Growth, Fatty Acid Composition and Muscle Alpha-Tocopherol Concentration of African Catfish, Clarias gariepinus," Aquaculture, Vol. 215, No. 1-4, 2003, pp. 229-243. 
[27] W. K. Ng, T. Sigholt and J. G. Bell, "The Influence of Environmental Temperature on the Apparent Nutrient and Fatty Acid Digestibility in Atlantic Salmon (Salmo salar L.) Fed Finfishing Diets Containing Different Blends of Fish Oil, Rapeseed Oil and Palm Oil," Aquaculture Research, Vol. 35, 2004, pp. 1228-1237.

[28] J. Fonseca-Madrigal, V. Karalazos, P. J. Campbell, J. G. Bell and D. R. Tocher, "Influence of Dietary Palm Oil on Growth, Tissue Fatty Acid Compositions, and Fatty Acid Metabolism in Liver and Intestine in Rainbow Trout (Oncorhynchus mykiss)," Aquaculture Nutrition, Vol. 11, No. 4, 2005, pp. 241-250.

[29] M. A. Piedecausa, M. J. Mazón, B. García García and M. D. Hernández, "Effects of Total Replacement of Fish Oil by Vegetable Oils in Sharpsnout Seabream (Diplodus puntazzo) Diets," Aquaculture, Vol. 263, No. 1-4, 2007 pp. 211-219.

[30] B. E. Torstensen, Ø. Lie and L. Froyland, "Lipid Metabolism and Tissue Composition in Atlantic Salmon (Salmo salar L.) - Effects of Capelin-, Palm- and Oleic Acid Enriched Sunflower Oil as Dietary Sources," Lipids, Vol. 35 , No. 6, 2000, pp. 653-664.

[31] G. Rosenlund, A. Obach, M. G. Sandberg, H. Standal and K. Tviet, "Effect of alternative lipid sources on long term growth performance and quality of Atlantic salmon (Salmo salar)," Aquaculture Research, Vol. 32, Suppl. 1, 2001, pp. 323-328.

[32] M. J. Caballero, A. Obach, G. Rosenlund, D. Montero, M. Gisvold and M. S. Izquierdo, "Impact of Different Dietary Lipid Sources on Growth, Lipid Digestibility, Tissue Fatty Acid Composition and Histology of Rainbow Trout, Oncorhynchus mykiss," Aquaculture, Vol. 214, No. 1-4, 2002, pp. 253-271.

[33] E. A. Bendiksen, O. K. Berg, M. Jobling, A. M. Arnesen, and K. Masøval, "Digestibility, Growth and Nutrient Utilisation of Atlantic Salmon parr (Salmo salar L.) in Relation to Temperature, Feed Fat Content and Oil Source," Aquaculture, Vol. 224, 2003, 283-299.

[34] D. S. Francis, G. M. Turchini, P. L. Jones and S. S. De Silva, "Dietary Lipid Source Modulates in Vivo Fatty Acid Metabolism in the Freshwater Fish, Murray Cod (Maccullochella peelii peelii)," Journal of Agricultural and Food Chemistry, Vol. 55, No. 4, 2007, pp. 15821591.

[35] R. E. Olsen and E. Ringø, "Lipid Digestibility in Fish: A Review," Recent Research Developments in Lipid Research, Vol. 1, 1997, pp. 199-265.

[36] D. S. Francis, G. M. Turchini, P. L. Jones and S. S. De Silva, "Effects of Dietary Oil Source on the Growth and Fillet Fatty Acid Composition of Murray Cod, Maccullochella peelii peelii," Aquaculture, Vol. 253, No. 1-4, 2006, pp. 547-556.

[37] G. M. Turchini, F. Caprino, I. Giani, S. Panseri, F. Bellagama, V. M. Moretti and F. Valfré, "The Relative Absorption of Fatty Acids in Brown Trout (Salmo trutta) Fed a Commercial Extruded Pellet Coated with Different Lipid Sources," Italian Journal of Animal Science, Vol. 4,
No. 3, 2005, pp. 241-252.

[38] K. H. Kiessling, and A. Kiessling, "Selective Utilization of Fatty Acids in Rainbow Trout (Oncorhynchus mykiss Walbaum) Red Muscle Mitochondria," Canadian Journal of Zoology, Vol. 71, 1993, pp. 248-251.

[39] Ø. Lie, E. Lied and G. Lambertsen, "Liver Retention of Fat and Fatty Acids in Cod (Gadus morhua) Fed Different Oils," Aquaculture, Vol. 59, No. 3-4, 1986, pp. 187196.

[40] S. J. Kaushik, "Recent Developments in the Nutrition and Feeding of Marine Finfish of Interest to the Mediterranean," Communication at INVE Conference Nutritional and the improvement of the sea bass and sea bream production in the Mediterranean Region, ALIIA Trades Show, Thessaloniki, Greece, 1997.

[41] A. G. J. Tacon, "Lipid Nutritional Pathology in Farmed Fish," Archives in Animal Nutrition, 1996, Vol. 49, No. 1, pp. 33-39.

[42] D. Montero, L. E. Robaina, J. Socorro, S. Panseri, F. Bellagama, V. M. Moretti and Valfré, "Alteration of Liver and Muscle Fatty Acid Composition in Gilthead Seabream (Sparus aurata) Juveniles Held at High Stocking Density and Fed an Essential Fatty Acid Deficient Diet," Fish Physiology and Biochemistry, Vol. 24, No. , 2001, pp. 63-72.

[43] E. Spisni, M. Tugnoli, A. Ponticelli, T. Mordenti and V. Tomasi, "Hepatic Steatosis in Artificially Fed Marine Teleosts," Journal of Fish Diseases, Vol. 21, No. 3, 1998, pp. 177-184.

[44] M. N. Alexis, "Fish Meal and Fish Oil Replacers in Mediterranean Marine Fish Diets," In: A. Tacon and B. Basurco, Eds., Feeding Tomorrow's Fish, Proceedings of the Workshop of the CIHEAM Network on Technology of Aquaculture in the Mediterranean (TECAM) Cahiers Options Méditerranéennes, Vol. 22, 1997, pp. 183-204.

[45] National Research Council, "Nutrient Requirement of Fish," National Academy Press, Washington DC, 1993.

[46] J. D. Castell, R. O. Sinnhuber, J. H. Wales and J. D. Lee, "Essential Fatty Acids in the Diet of Rainbow Trout (Salmo gairdneri): Growth, Feed Conversion and Some Gross Deficiency Symptoms," Journal of Nutrition, Vol. 102, No. 1, 1972, pp. 77-86.

[47] E. Fountoulaki, A. Vasilaki, R. Hurtado, K. Grigorakis, I. Karacostas, I. Nengas, G. Rigos, Y. Kotzamanis, B. Venou and M. N. Alexis, "Fish Oil Substitution by Vegetable Oils In Commercial Diets for Gilthead Sea Bream (Sparus aurata L.); Effects on Growth Performance, Flesh Quality and Fillet Fatty Acid Profile Recovery of Fatty Acid Profiles by a Fish Oil Finishing Diet under Fluctuating Water Temperatures," Aquaculture, Vol. 289, No. 3-4, 2009, pp. 317-326.

[48] D. Montero, M. J. Robaina, R. Caballero, R. Gines and M. S. Izquierdo, "Growth, Feed Utilization and Flesh Quality of European Sea Bass (Dicentrarchus labrax) Fed Diets Containing Vegetable Oils: A Time-Course Study on the Effect of a Re-feeding Period with a 100\% Fish Oil Diet," 
Aquaculture, Vol. 248, No. 1-4, 2005, pp. 121-134.

[49] G. Mourente and J. G. Bell, "Partial Replacement of Dietary Fish Oil with Blends of Vegetable Oils (Rapeseed, Linseed and Palm Oils) in Diets for European Sea Bass (Dicentrarchus labrax L.) over a Long Term Growth Study: CEffects on Muscle and Liver Fatty Acid Composition and Effectiveness of a Fish Oil Finishing Diet," Comparative Biochemistry and Physiology Part B: Biochemistry and Molecular Biology, Vol. 145, No. 3-4, 2006, pp. 389-399.

[50] C. Regost, J. Arzel, M. Cardinal, G. Rosenlund and S. J. Kaushik, "Total Replacement of Fish Oil by Soybean or Linseed Oil with a Return to Fish Oil in Turbot (Psetta maxima) II," Flesh Quality Propertiesi, Aquaculture, Vol. 220, No. 1-4, 2003, 737-747.

[51] D. Menoyo, M. S. Izquierdo, L. E. Robaina, R. Ginés, C. J. López-Bote, and J. M. Bautista, "Adaptation of Lipid Metabolism, Tissue Composition and Flesh Quality in Gilthead Sea Bream (Sparus aurata) to the Fish Oil Replacement by Linseed and Soybean Oils," British Journal of Nutrition, Vol. 92, No. 1, 2004, pp. 41-52.

[52] B. E. Torstensen, L. Froyland and O. Lie, "Replacing Dietary Fish Oil with Increasing Levels of Rapeseed Oil and Olive Oil-Effects on Atlantic Salmon (Salmo salar L) Tissue Composition and Lipoprotein Lipid Composition and Lipogenic Enzyme Activities," Aquaculture Nutrition, Vol. 10, No. 3, 2004, pp. 175-192.

[53] L. Madsen, L. Froyland, E. Dyroy, K. Helland and R. K. Berge, "Docosahexaenoic and Eicosapentaenoic Acids Are Differently Metabolized in Rat Liver during Mito- chondria and Peroxisome Proliferation," The Journal of Lipid Research, Vol. 39, 1998, pp. 583-593.

[54] J. G. Bell, J. McEvoy, D. R. Tocher, F. McGhee, P. J. Campbell and J. R. Sargent, "Replacement of Fish Oil with Rapeseed Oil in Diets of Atlantic Salmon (Salmo salar) Affects Tissue Lipid Compositions and Hepatocyte Fatty Acid Metabolism," Journal of Nutrition, Vol. 131, 2001, pp. 1535-1543.

[55] M. J. Caballero, M. S. Izquierdo, E. Kjørsvik, D. Montero, J. Socorro, A. J. Fernández and G. Rosenlund, "Morphological Aspects of Intestinal Cells from Gilthead Seabream (Sparus aurata) Fed Diets Containing Different Lipid Sources," Aquaculture, Vol. 225, No. 1-4, 2003, pp. 325-340.

[56] S. Morais, W. Koven, I. Rønnestad, M. T. Dinis and L. E. C. Conceição, "Dietary Protein: Lipid Ratio and Lipid Nature Affects Fatty Acid Absorption and Metabolism in a Teleost Larva," British Journal of Nutrition, Vol. 93, No. 6, 2005, pp. 813-820.

[57] R. E. Olsen, R. Myklebust, T. Kaino and E. Ringø, "Lipid Digestibility and Ultrastructural Changes in the Enterocytes of Arctic Charr (Salvelinus alpinus L.) Fed Linseed Oil and Soybean Lecithin," Fish Physiology and Biochemistry, Vol. 21, No. 1, 1999, pp. 35-44.

[58] R. E. Olsen, R. Myklebust, E. Ringø and T. M. Mayhew, "The Influences of Dietary Linseed Oil and Saturated Fatty Acids on Caecal Enterocytes in Arctic Charr (Salvelinus alpinus L.): A Quantitative Ultrastructural Study," Fish Physiology and Biochemistry, Vol. 22, No. 3, 2000, pp. 207-216. 